\section{Nyttig om løvetannbarn}

Anne Inger Helmen Borge Resiliens

Risiko og sunn utvikling. 197 s, tab, ill. Oslo: Gyldendal Akademisk, 2010. Pris NOK 345 ISBN 978-82-05-39066-9

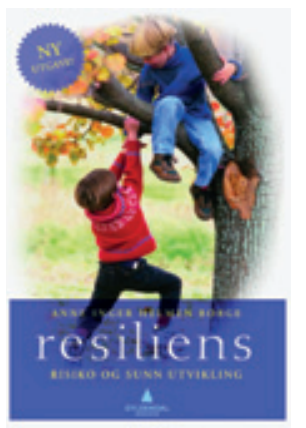

Forfatteren er professor i utviklingspsykologi ved Universitetet i Oslo. Begrepet resiliens omhandler fenomener som bidrar til at barn utvikler psykisk motstandskraft og klarer seg, til tross for vanskelige oppvekstbetingelser. Resiliens kan være i samfunnsmessige strukturer, mellom mennesker, som mellom omsorgsgiver og barn, eller i barnet selv.

Boken er beregnet som lærebok for studenter innen psykologi, barnevernspedagogikk og sosionomutdanningen, men målgruppen er også helsearbeidere som møter barn, unge og familier i risikosonen. Hensikten er primærforebyggende; å peke på hvordan risikobarn kan hjelpes tidligere og på bedre måter, slik at de får et tilfredsstillende livsløp.

Det er åtte kapitler. I første kapittel definerer forfatteren begrepet, og beslektede begreper omtales som løvetannbarn, mestringsperspektiv, salutogenese (det motsatte av patogenese, dvs. det som skaper helse) samt opplevelse av sammenheng (sense of coherence), som kan være avgjørende for om individet bryter sammen eller ikke. Første kapittel avsluttes med de første studiene på barn født i 1955 på Kauai på Hawaii og deres livsløp. En tredel av kohorten som var utsatt for risiko, klarte seg likevel. De neste kapitlene handler om alt fra elendighetsperspektiv til resiliens, resiliens i forhold til individuell, familiebasert og samfunnsmessig risiko, resiliens i forhold til antisosial atferd, etnisitet og politisk vold, livsløp og resiliens i voksen alder, og resiliens og genetikk.

Teksten brytes opp av faktabokser og oversikter. Boken har en fyldig litteraturliste og stikkordregister. Den er oppdatert på forskning som er publisert siden førsteutgaven utkom i 2003, og de to siste kapitlene er nyskrevne.

I psykiatrien har søkelyset tidligere vært på traumer og risikofaktorer for utvikling av psykisk lidelse. Resilienstenkningen balanserer, men erstatter ikke patogenesetenkningen. Samtaleformer som vektlegger resiliensperspektivet, er narrativ og løsningsfokusert terapi. Her omskriver man livsfortellingen eller legger vekt på hvordan man har klart seg, på tross av traumatiske opplevelser. Det kan være mer effektfullt enn å fokusere på traumet i seg selv, og bety forskjellen mellom å se seg selv som et offer, eller som en som har klart seg. Men utviklingen av den terapeutiske alliansen er forutsetningen for terapeutisk effekt. Alliansen skapes ved at terapeuten er der pasienten er, og først lytter til pasientens smerte. Når alliansen er etablert, er det rom for å bringe inn andre perspektiver. Dette eksemplet fra psykoterapien illustrerer at kunnskapen på resiliensfaktorer kommer som et tillegg til den kunnskapen vi allerede har om risikofaktorer, og at begge trengs for å skape en helhetlig forståelse av et menneskes situasjon.

Forfatteren kontrasterer risiko og resiliens, men holder frem begge perspektivene. Jeg anbefaler boken til klinikere innen faget som ønsker å oppdatere seg på ny kunnskap om prosesser som former et menneske på godt og vondt.

\section{Øystein Sørbye}

Senter for psykisk helse barn og ungdom Oslo universitetssykehus

\section{Litt for dansk om ernæring}

Arne Astrup, Jørn Dyerberg,

Steen Stender et al, red.

Menneskets ernæring

3. utg. 624 s, tab, ill. København: Munksgaard Danmark, 2010. Pris DKK 558

ISBN 978-87-628-0884-3

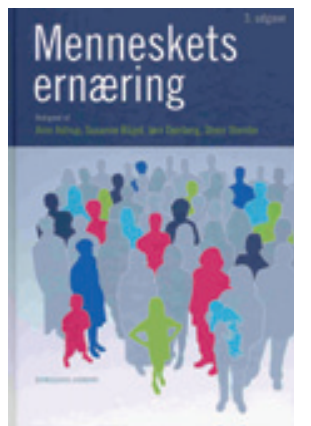

Det er tredje utgave av den danske læreboken Menneskets ernoering som nå foreligger, med tidligere versjoner fra 1997 og 2005. Bidragsyterne har både revidert og utvidet med flere nye kapitler, og

det er blitt en stor og innholdsrik lærebok.

Boken er inndelt i sju seksjoner: innledning, ernæringsfysiologi, næringsstoffer, fra næringsstoffer til fødevarer og kost, særlige fødevarer, ernæring hos utsatte grupper og til slutt historie og perspektiver. Delen om ernæring hos utsatte grupper, bl.a. gravide, barn og eldre, utgjør om lag en tredel. Denne delen inneholder også flere kapitler om kost i forbindelse med de viktigste risikofaktorene for sykdom, som blodtrykk, overvekt og åreforkalkning, i tillegg til ved manifest sykdom som diabetes, kreft og osteoporose. Det er også et kapittel om endringer i næringsinnhold gjennom bearbeiding, tilbereding og lagring av matvarer, noe som mangler i de tilsvarende norske lærebøkene.

Ernæring er et svært aktuelt og omdiskutert tema. Kapitlet om prinsipper for kunnskapsbaserte næringsstoffanbefalinger er en viktig gjennomgang av metoder for kost- holdsforskning, og samtidig stiller man spørsmål rundt gjennomføringen av kostholdsundersøkelser og resultatene av dem.

Dansk er stort sett greit å lese for nordmenn, og den grunnleggende informasjonen er universell. Kapitlet om ernæringspolitiske tiltak i EU gir viktig informasjon, selv om Norge ikke er med i EU, men en del av politikken blir for spesifikk dansk. Forfatterne introduserer også Det nye nordiske kjøkken, en viktig vektlegging av det spesielle ved matvarene i de nordiske landene. Kapitlet om ernæringsforskningens historie i Danmark er for spesielt interesserte, med en gjennomgang av ti viktige personer innen dansk ernæringshistorie.

Menneskets erncering har et rent og enkelt utseende. Det er noen fargeillustrasjoner, men det kunne godt vært flere for å skape en mer spennende design. Lærebøkene i ernæring har mye å lære av kokeboktradisjonen i forhold til å gjøre det fristende å lese.

Målgruppen er studenter som beskjeftiger seg med ernæringsspørsmål. Norske studenter vil nok savne det norske perspektivet og mer spesifikk informasjon om norske forhold og norsk ernæringspolitikk. For viderekomne gir boken et videre perspektiv utover det norske, men for studenter vil mer særnorsk informasjon og norske retningslinjer være et nødvendig supplement.

Dette er en oversiktlig lærebok. Forfatterne går utover det grunnleggende og byr på viktige problemstillinger innen et spennende og meget aktuelt ernæringsfag, men boken vil nok være «litt for dansk» for norske lesere.

\section{Astrid Marie Nylenna}

Avdeling for grupperettet folkehelsearbeid Helsedirektoratet

\section{Hvorfor fem om dagen?}

\section{Aksel Bernhoft, red}

\section{Bioactive compounds in plants}

Benefits and risks for man and animals.

255 s, tab, ill. Oslo: Novus forlag, 2010

ISBN 978-82-7099-583-7

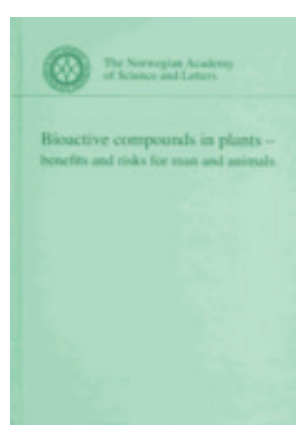

Denne boken er en artikkelsamling basert på en foredragsserie, gitt på et symposium i Det Norske Videnskaps-Akademi i november 2008 . Målgruppen er ernæringsfysiologer, toksikologer, farmasøyter, leger, veterinærer, medisin- og matprodusenter og andre som er interessert i temaet. Boken består av et innledende sammendrag om 